\title{
SANDEELS IN THE DIETS OF SEALS: APPLICATION OF NOVEL AND CONVENTIONAL METHODS OF ANALYSIS TO FAECES FROM SEALS IN THE MORAY FIRTH AREA OF SCOTLAND
}

\author{
G.J. PIERCE, P.R. BOYLE, J.S.W. DIACK* AND I. CLARK \\ Department of Zoology, University of Aberdeen, Tillydrone Avenue, Aberdeen, AB9 2TN \\ *Present address: Department of Medical Genetics, Medical School, Aberdeen Royal Infirmary, Aberdeen
}

\begin{abstract}
Serological methods for prey identification have been applied to detection of residues of sandeel (Ammodytidae) protein in faeces of common seals (Phoca vitulina) and grey seals (Halichoerus grypus) from the Moray Firth, north-east Scotland. Antisera raised to muscle protein from Ammodytes marinus were evaluated by testing their reactions with protein extracts made from a range of North Sea fish species and protein residues in in vitro digestates, seal digestive tracts and seal faeces. It was concluded that, using fused rocket immuno-electrophoresis, linkage of precipitin peaks from unknown samples with peaks from standard sandeel extract was a reliable indicator of the presence of sandeel in the unknown sample. Seasonal variation in the incidence of sandeels in common seal diet in the Moray Firth was examined by identifying otoliths, bones, and proteins, and all three methods indicated that sandeels occurred in the majority of samples tested in the summer, but were less important during the winter. Proteins were detected in fewer samples than otoliths, particularly in February and March. Possible reasons for this difference are discussed. Serological identification of sandeel proteins is potentially applicable to dietary studies on all marine predators.
\end{abstract}

\section{INTRODUCTION}

Serological methods of prey identification are well-established in studies of marine trophic interactions (e.g. Boreham \& Ohiagu, 1978; Boyle et al., 1986; Feller \& Gallagher, 1982; Feller et al., 1979; Grisley \& Boyle, 1985, 1988) and have recently been applied to the diets of seabirds (Walter et al., 1986) and marine mammals (Pierce et al., 1990b).

Antisera raised to muscle protein extracts from salmon (Salmo salar Linnaeus) reacted specifically with Salmonidae proteins in digestive tract contents of common seals (Phoca vitulina Linnaeus), grey seals (Halichoerus grypus Fabricius), and bottle-nosed dolphins (Tursiops truncatus Montagu), and in faeces from seals fed on salmon (Pierce et al., 1990b). However, the serological approach has not previously been applied to screening seal faeces collected in the wild.

The selection of sandeels for a field test of serological identification of prey in seal faeces is appropriate for two reasons. Firstly, sandeels (Ammodytidae) are an important food source for both grey and common seals (McConnell et al., 1984; Pierce et al., 1989, 1990a, in press a, b), and sandeel protein residues are likely to be present in a significant proportion of field samples. Secondly, sandeel bones and otoliths are frequently found 
intact in seal faeces (e.g. McConnell et al., 1984; Pierce et al., 1990a, in press b), allowing independent verification of the presence of sandeel remains.

In the wider ecological context, sandeels are important prey for a variety of other marine predators: fish (Daan, 1989; ICES, 1989), seabirds (Bailey, 1986), and cetaceans (e.g. Payne et al., 1986), and are also fished commercially in Shetland and other parts of the North Sea (Kunzlik, 1989).

Although sandeel hard parts are readily identifiable in seal faeces, there are various reasons why hard parts might be absent from these and other types of sample,e.g. protein residues and hard parts may pass through predator digestive tracts at different rates, hard parts may be fragmented (as by a gizzard), or, in the case of stomach lavages, might not be collected in the sample. In such circumstances, and for prey with friable bones (or no bones), serological methods may represent the only possible means of prey identification.

The Moray Firth, Scotland, has resident populations of both common seals and grey seals: at least 1000 common seals live in the Beauly, Cromarty, Dornoch and Inverness Firths (P. Thompson, unpublished data), and over 300 grey seals were counted in the Dornoch Firth in the summer of 1987. Caves and beaches at Helmsdale, to the north of the Moray Firth, are used by breeding grey seals (DAFS, unpublished data).

The present paper describes tests of new antisera raised to Ammodytes marinus (Raitt), and the application of these antisera to identification of sandeel proteins in faeces of common seals and grey seals, collected in the Moray Firth area during 1987 and 1988. The incidence of sandeels evaluated using the serological approach is compared with results from sandeel bones and otoliths.

\section{METHODS}

Methods for sample preparation, protein extraction, raising and testing antisera, and screening samples, are as described in Pierce et al. (1990b) unless otherwise stated.

\section{Fish protein extracts}

Muscle protein extracts ( $50 \mathrm{mg}$ protein $\mathrm{ml}^{-1}$ ) were prepared from Ammodytes marinus, for antiserum production, and from a range of North Sea fish species for testing antiserum specificity (see Table 1). Further extracts were made from cod, herring, mackerel, salmon, sandeel, and whiting, digested in vitro for $30 \mathrm{~min}$, also from sandeel digested in vitro for $10,20,60,90$ and $120 \mathrm{~min}$.

\section{Seal digestive tracts and faeces}

Protein extracts were made from digestive tract contents of four grey seals: three guts contained large numbers of sandeel otoliths and bones; the other, remains of lumpsuckers (Cyclopterus lumpus Linnaeus), clupeids and gadids, but no sandeels. Protein extracts were prepared from faeces of captive common and grey seals which had been fed on (a) salmon, (b) cod, (c) mackerel, and (d) herring and sprat. 
Table 1. Species of fish used for testing antiserum specificity. Taxonomic authorities for all species are given in Wheeler (1969)

\begin{tabular}{|c|c|c|c|}
\hline \multicolumn{4}{|c|}{ (a) Selachii } \\
\hline Pleurotremata: & $\begin{array}{l}\text { Scyliorhinidae: } \\
\text { Squaloidae: }\end{array}$ & $\begin{array}{l}\text { Dogfish } \\
\text { Spur-dog }\end{array}$ & $\begin{array}{l}\text { Scyliorhinus sp. } \\
\text { Squalus acanthias }\end{array}$ \\
\hline Hypertremata: & Rajiidae: & $\begin{array}{l}\text { Starry ray } \\
\text { (b) Pisces }\end{array}$ & Raja radiata \\
\hline Isospondyli: & $\begin{array}{l}\text { Argentinidae: } \\
\text { Clupeidae: } \\
\text { Salmonidae: }\end{array}$ & $\begin{array}{l}\text { Argentine } \\
\text { Herring } \\
\text { Salmon } \\
\text { Trout }\end{array}$ & $\begin{array}{l}\text { Argentina sphyraena } \\
\text { Clupea harengus } \\
\text { Salmo salar } \\
\text { Salmo trutta }\end{array}$ \\
\hline Anacanthini: & Gadidae & $\begin{array}{l}\text { Cod } \\
\text { 4-bearded rockling } \\
\text { Hake } \\
\text { Norway pout } \\
\text { Pollack } \\
\text { Poor-cod } \\
\text { Silvery pout } \\
\text { Whiting }\end{array}$ & $\begin{array}{l}\text { Gadus morhua } \\
\text { Rhinonemus cimbrius } \\
\text { Merluccius merluccius } \\
\text { Trisopterus esmarkii } \\
\text { Pollachius pollachius } \\
\text { Trisopterus minutus } \\
\text { Gadiculus argenteus } \\
\text { Merlangius merlangus }\end{array}$ \\
\hline Percomorphi: & $\begin{array}{l}\text { Carangidae: } \\
\text { Scombridae: } \\
\text { Callionymidae: }\end{array}$ & $\begin{array}{l}\text { Scad } \\
\text { Mackerel } \\
\text { Dragonet }\end{array}$ & $\begin{array}{l}\text { Trachurus trachurus } \\
\text { Scomber scombrus } \\
\text { Callionymus lyra }\end{array}$ \\
\hline Scleroparei: & $\begin{array}{l}\text { Scorpaenidae: } \\
\text { Triglidae } \\
\text { Cottidae: }\end{array}$ & $\begin{array}{l}\text { Norway haddock } \\
\text { Red gurnard } \\
\text { Bullrout }\end{array}$ & $\begin{array}{l}\text { Sebastes viviparus } \\
\text { Aspitrigla cuculus } \\
\text { Myoxocephalus scorpius }\end{array}$ \\
\hline Heterosomata: & $\begin{array}{l}\text { Bothidae: } \\
\text { Pleuronectidae: }\end{array}$ & $\begin{array}{l}\text { Megrim } \\
\text { Flounder } \\
\text { Long rough dab } \\
\text { Plaice } \\
\text { Witch } \\
\text { Dover sole }\end{array}$ & $\begin{array}{l}\text { Lepidorhombus whiffiagonis } \\
\text { Platichthys flesus } \\
\text { Hippoglossoides platessoides } \\
\text { Pleuronectes platessa } \\
\text { Glyptocephalus cynoglossus } \\
\text { Solea solea }\end{array}$ \\
\hline
\end{tabular}

Throughout 1988, regular visits were made to common seal haul-out sites, principally intertidal sandbanks, in the Beauly, Cromarty, Dornoch and Inverness Firths (Figure 1). All faeces found were collected. Common seal faeces were obtained in all months but grey seal faeces were found only in the months April to July. Grey seal faeces were also collected at Helmsdale in April. Protein extracts were made from all samples, as above. For months in which more than 20 samples of either species were obtained, 20 of those samples were randomly selected for testing.

\section{Raising antisera}

Two Dutch rabbits $(K, L)$ were immunized with sandeel muscle protein extract. The protocol was similar to that described in Pierce et al. (1990b), except that booster injections were given 1 month $(0.5 \mathrm{ml}$ extract $+0.5 \mathrm{ml}$ Freunds incomplete adjuvant $)$ and 2 months (1 $\mathrm{ml}$ extract) after the initial injection. 


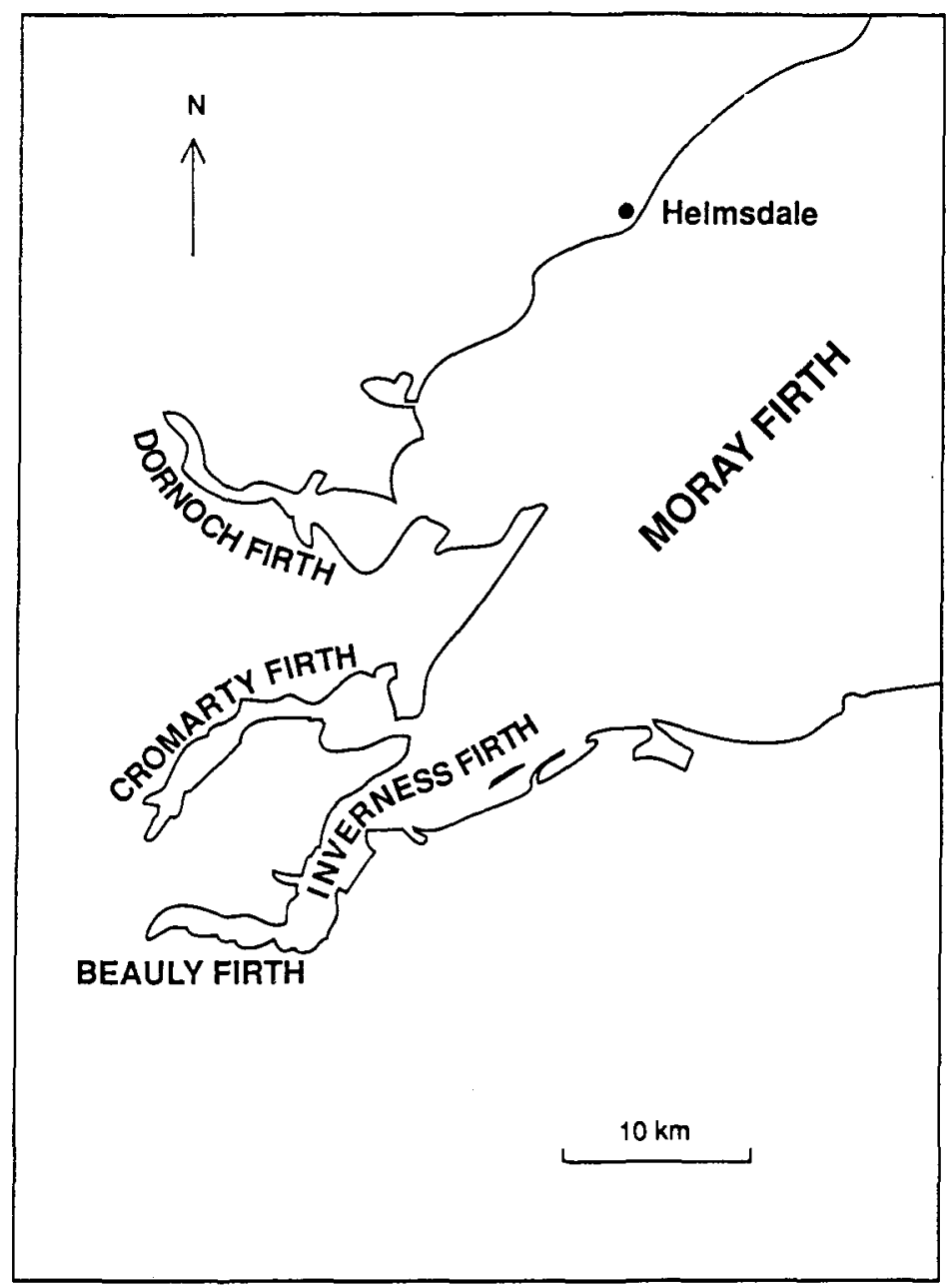

Figure 1. The Moray Firth study area.

\section{Testing antisera}

Antiserum titre was evaluated subjectively using homologous crossed immunoelectrophoresis (CIE; Weeke, 1973).

Reactions of other proteins with the antisera were evaluated using fused rocket immuno-electrophoresis (FRIE; Svendsen, 1973). Reactions were assessed visually, noting the number of precipitin peaks arising from the unknown samples, and the number of links between peaks from the unknowns and peaks from the adjacent standards. Linking, in which adjacent peaks form a continuous smooth curve, indicates that the proteins were indistinguishable to the antiserum. Where a peak terminated on contact with an adjacent peak, but the two peaks met at a more or less acute angle, the reaction was scored as a 'partial link'. 
To test reactions with the chronological series of sandeel in vitro digestates $\left(50 \mathrm{mg} \quad \mathrm{ml}^{-}\right.$ ${ }^{1)}$, raw sandeel protein extract $\left(10 \mathrm{mg} \mathrm{ml}^{-1}\right)$ was used as the standard. For subsequent tests, two sets of standards were used: raw sandeel protein (Standard 1) and sandeel digestate ( $30 \mathrm{~min}$; Standard 2). Samples were arranged so that each unknown was adjacent to both standards. This procedure was used for:

(a) Raw protein from other fish species $\left(10 \mathrm{mg} \mathrm{ml}^{-1}\right)$;

(b) In vitro digestates from other fish species $\left(50 \mathrm{mg} \mathrm{ml}^{-1}\right)$;

(c) Digestive tract contents $\left(50 \mathrm{mg} \mathrm{ml}^{-1}\right)$;

(d) Faeces from captive seals $\left(50 \mathrm{mg} \mathrm{ml}^{-1}\right.$ );

(e) Faeces from grey seals at Helmsdale, of which 19 out of 21 contained hard remains of sandeels $\left(50 \mathrm{mg} \mathrm{ml}^{-1}\right)$.

Evaluation of the incidence of sandeels in seal faeces

\section{Proteins}

Extracts from each wild faecal sample were run into antiserum $\mathrm{K}$, with sandeel in vitro digestate ( $30 \mathrm{~min})$ used as the standard. Reactions were scored as negative (no peaks), positive (peaks but no linkage) and linked (full linkage to peaks in the standards). The number of linked peaks was counted in each case. Each author scored all gels independently, with gels being repeated where there was any doubt as to the presence of links.

\section{Hard remains}

Sandeel otoliths were counted and sandeel bones were scored as present or absent. Otoliths of different species of sandeel could not be distinguished: although, for example, otoliths of the greater sandeel (Hyperoplus lanceolatus Lesauvage) are often larger than those of Ammodytes marinus or A.tobianus (Linnaeus), the size ranges are overlapping and all species have very similar otoliths (Harkonen, 1986). Other prey remains were also identified and other otoliths were counted. The co-occurrence of hard remains and proteins was evaluated using Mann-Whitney U tests, Spearman's rank correlation coefficients, and analysis of variance. Otolith numbers were transformed to logarithms $\left(\log _{10}[\mathrm{~N}+1]\right)$ prior to analysis of variance.

\section{RESULTS}

\section{Antiserum testing}

\section{Reactions with sandeel protein}

Both antisera showed reasonably strong reactions with proteins in raw sandeel protein extracts (Figure 2). Antiserum L was of higher titre than antiserum K (variability between rabbits is commonly seen when producing antisera). The antisera reacted with in vitro digested sandeel protein, and linkage was seen between raw and in vitro digested proteins (Figure 3). 


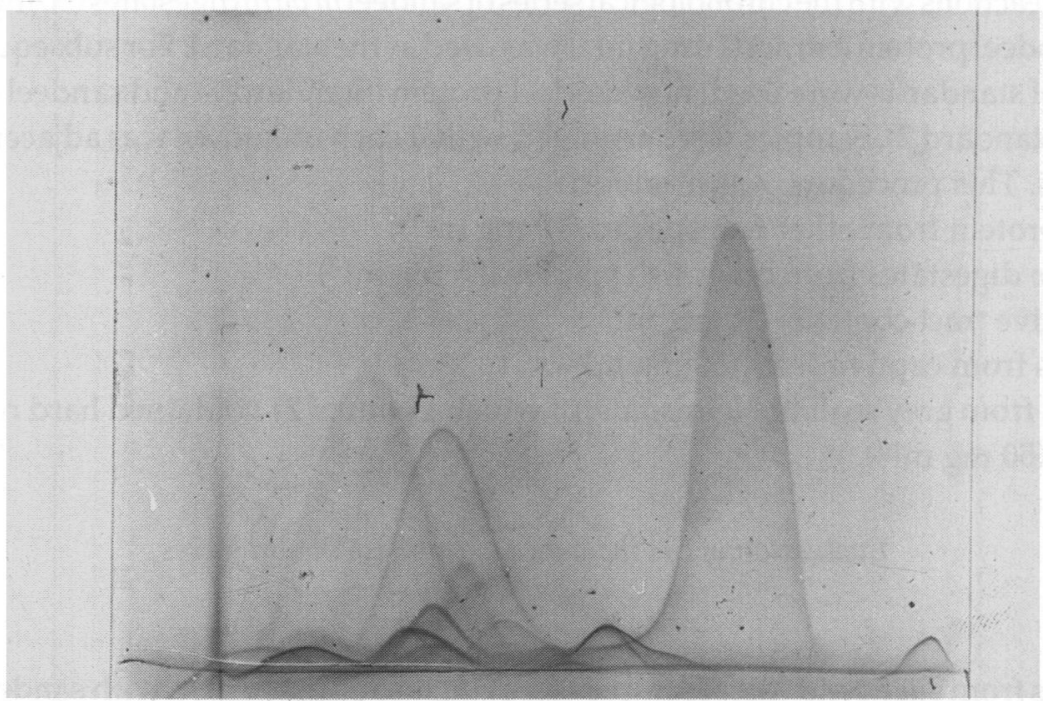

Figure 2. Reaction between sandeel antiserum $\mathrm{L}$ and homologous muscle protein extracts, visualised by CIE (rabbit L). Each peak represents an antigen in the sandeel extract which is recognised by the antiserum.

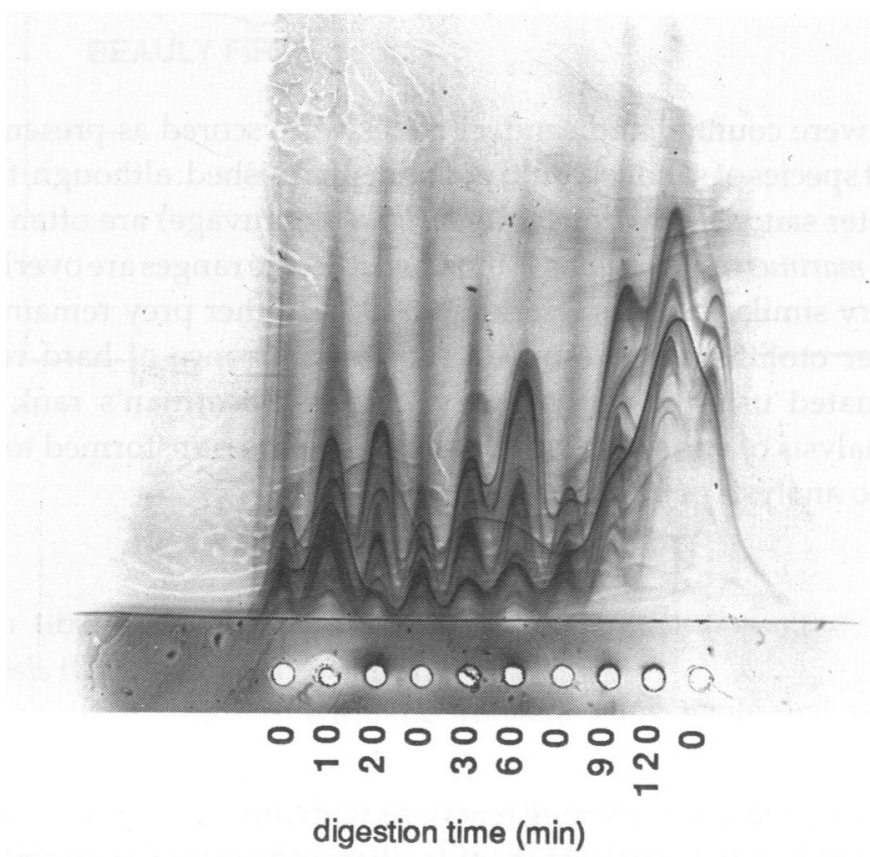

Figure 3. Reaction of sandeel antiserum $\mathrm{L}$ with in vitro digested sandeel proteins visualised by FRIE. In FRIE the different antigen peaks within a sample are separated on the vertical axis, as a series of 'rockets'. Fusion (linkage) of peaks from adjacent rockets indicates that the same antigen occurs in the linked samples. Several antigenic components of sandeel protein extract are seen to survive prolonged in vitro digestion, although becoming less strongly antigenic, as indicated by the increased height of peaks. 
Reactions with proteins from other fish

Proteins from many of the other fish species tested reacted with the antisera, in some cases (e.g. plaice) strongly, although always producing fewer peaks than the sandeel extract and never fully linking with sandeel protein peaks (Figure 4). Partial linkage, with both standards, was apparent for mackerel, plaice, pollack, poor cod, Norway pout, Norway haddock, and whiting. No linkage was seen for the remaining species tested (Table 1).

Of the fish prepared as in vitro digestates, linkage with both standards was seen for cod. The other species tested reacted more weakly as in vitro digestates, with no linkage.

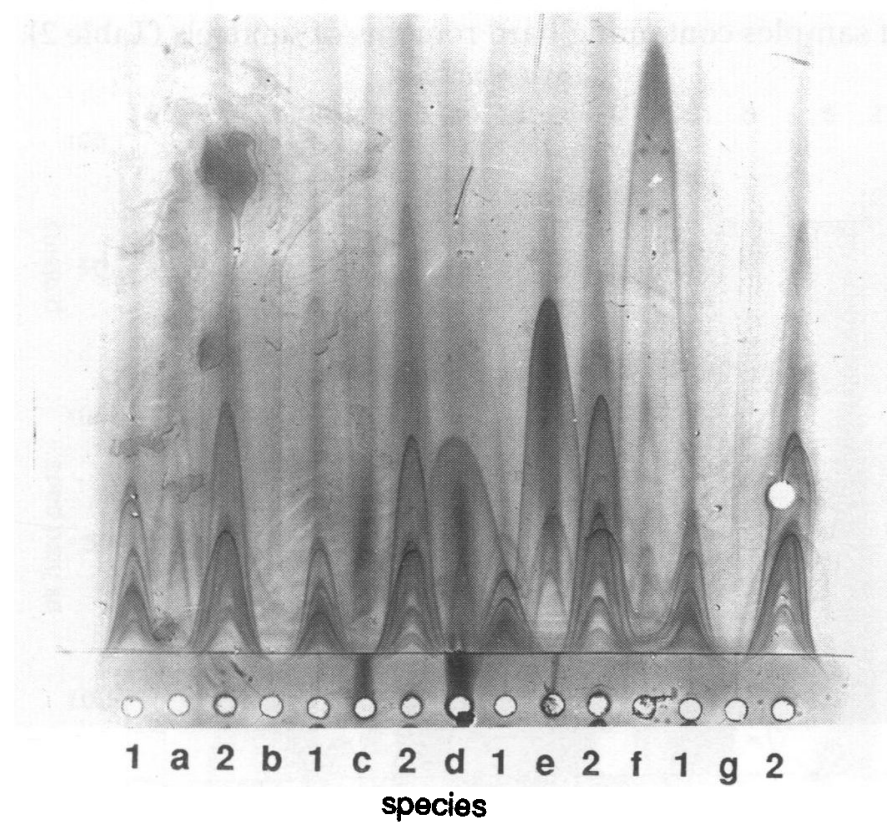

Figure 4. Reaction of sandeel antiserum $\mathrm{L}$ with protein extracts from some other North sea fish species (a) megrim, (b) silvery pout, (c) trout, (d) red gurnard, (e) plaice, (f) witch, (g) starry ray. Although there are distinct peaks, e.g. for plaice and red gurnard, the peaks do not link with peaks from the standard sandeel extracts 1 (raw sandeel) or 2 (30 min digestate).

\section{Reaction with seal samples}

Extracts from all sections of the three digestive tracts containing sandeel remains reacted strongly with the antiserum, with links between sandeel and sample protein peaks. Although the previous results indicate the possibility of linkage occurring with proteins from other fish species, the samples produced numerous peaks, and it is therefore likely that the proteins recognized were from sandeels. Samples from the fourth digestive tract, which contained no sandeel bones, did not react with the antiserum. 
Seventeen out of 21 faecal samples from grey seals at Helmsdale reacted with the antiserum, with clear links. Faecal samples from seals fed on diets of cod, herring, and salmon did not react with the antiserum. Some samples from seals fed on mackerel produced a weak reaction, with discernible single peaks, but no links.

\section{Screening of faecal samples from the Moray Firth}

The weaker antiserum $(\mathrm{K})$ was used for screening to minimize the likelihood of false positives. Reactions, with linkage, were obtained from 120 out of 248 samples (including the Helmsdale samples; see Figure 5). In most cases where sandeel proteins were recognized, hard parts were also present. However, sandeel proteins were detected in only two thirds of samples containing hard remains of sandeels (Table 2).

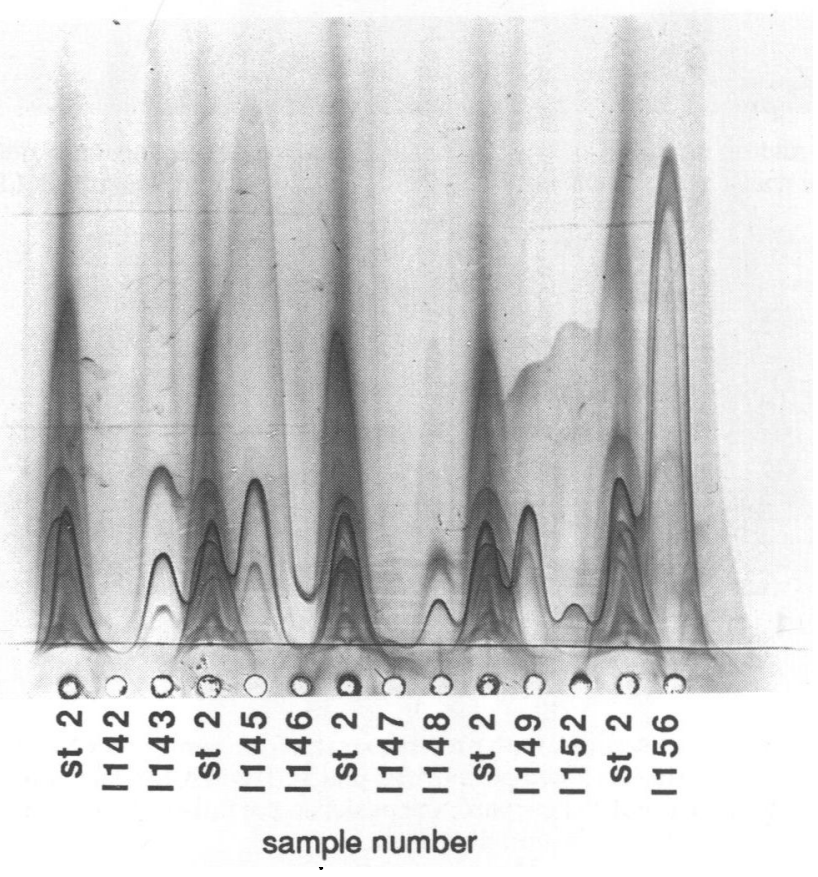

Figure 5. Reaction of sandeel antiserum $\mathrm{K}$ with protein extracts from common seal faeces collected in September 1988. Although few recognisable antigens remain, clear linkage is seen between peaks from samples and peaks from standard sandeel extract (st 2).

Table 2. Frequencies of occurrence for sandeel proteins and hard parts (otoliths or bones) in common seal faeces from the Moray Firth

\begin{tabular}{|c|c|c|c|c|c|c|c|c|}
\hline & & \multicolumn{2}{|c|}{ Bones } & \multicolumn{2}{|c|}{ Otoliths } & \multicolumn{2}{|c|}{ Hard parts } & \multirow[t]{2}{*}{ Total } \\
\hline & & - & + & - & + & - & + & \\
\hline Protein & - & 89 & 39 & 79 & 49 & 72 & 56 & 128 \\
\hline & + & 9 & 111 & 12 & 108 & 4 & 116 & 120 \\
\hline Total & & 98 & 150 & 91 & 157 & 76 & 172 & 248 \\
\hline
\end{tabular}


An analysis of variance was performed on log-transformed sandeel otolith numbers, with presence of otoliths from other species, presence of sandeel bones, presence of sandeel proteins, and season (dividing the year into four quarters), as grouping factors. The design was uneven and it was possible to investigate main effects only, ignoring possible interactions between factors. All four grouping factors had a significant effect on the number of sandeel otoliths: presence of otoliths from other fish $(F=9.08, P<0.01)$, presence of sandeel proteins $(F=23 \cdot 4, P<0.001)$, presence of sandeel bones $(F=63 \cdot 8, P<0 \cdot 001)$, and season $(F=3.31, P<0.05)$.

There was a low but significant inverse correlation between the number of sandeel otoliths in a sampleand the total number of otoliths from all other species $(r=-0 \cdot 297, \mathrm{~N}=248$, $P<0 \cdot 05)$.

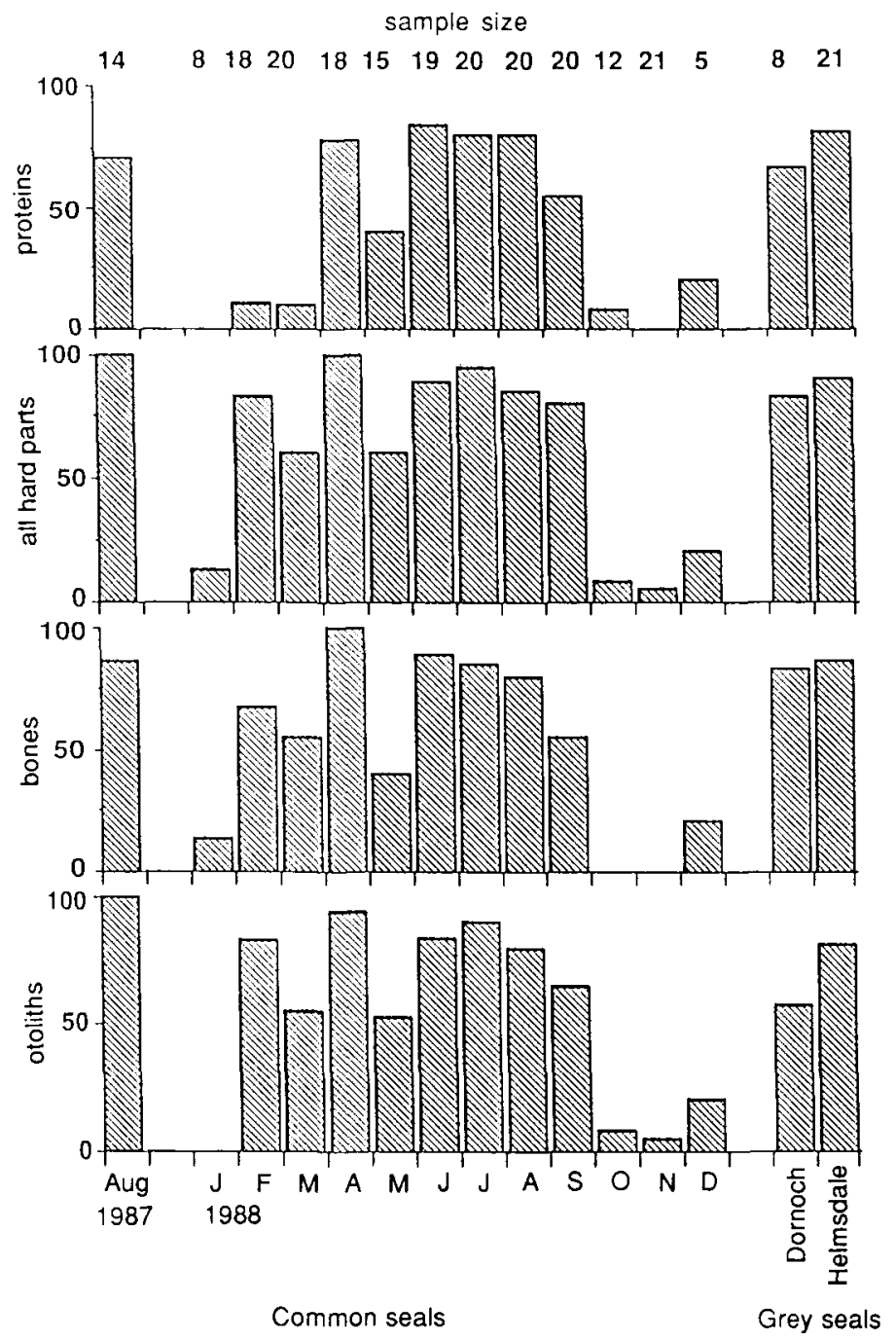

Figure 6. Seasonal variation in percentage frequency of occurrence of sandeels as revealed by different methods of detection. 
Samples in which no protein was detected contained fewer sandeel otoliths than samples in which protein was detected (median, $M_{1}=0, N_{1}=128 ; M_{2}=38 \cdot 5, N_{2}=120 ; P<0 \cdot 001$ ). However, the reverse was true for non-sandeel otoliths $\left(M_{1}=2.5, N_{1}=128 ; M_{2}=0, N_{2}=120\right.$; $P<0$ 001). Restricting the analysis to samples which contained sandeel bones, the above trends remained for both sandeel otoliths $\left(M_{1}=6, N_{1}=39 ; M_{2}=49, N_{2}=111 ; P<0.001\right)$ and nonsandeel otoliths $\left(M_{1}=0, N_{1}=39 ; M_{2}=0, N_{2}=111 ; P<0.01\right)$.

Examining the data on a monthly basis (Figure 6), it can be seen that sandeels formed an important component of the diet of seals in the Moray Firth in 1988, particularly in the summer months, when up to $100 \%$ of samples contained sandeel remains. The most obvious discrepancy between results from proteins and results from hard parts was in the months of February and March. The number of gadid otoliths (mostly whiting and $\operatorname{cod}$ ) in the samples was higher for February/March samples ( $N=39$, mean=4.21) than for the rest of the year $(\mathrm{N}=167$, mean=0.52) (Mann-Whitney $U$ test, $P<0.001)$.

\section{DISCUSSION}

Tests with proteins from a range of other fish species and with protein residues in seal faeces indicated that the antisera reacted much more strongly with sandeel (A. marinus) protein residues than with proteins from other species, and that the likelihood of misidentification was minimal for proteins remaining in seal faeces. However, the extent to which the antisera react with proteins from other species of sandeels has not been evaluated. In contrast to antisera raised to salmon and cod (Pierce et al., 1990b), sandeel antisera reacted strongly with homologous protein residues in seal faeces collected in the field. There is no reason to suppose that sandeel flesh is particularly resistant to digestion, but there are other possible explanations for the difference in antigenicity. In making muscle protein extracts from small fish such as sandeels it was difficult to exclude all other tissues, thus the high residual antigenicity in faeces might derive from, for example, relatively indigestible skin. Another possibility is that smaller prey, e.g. sandeels, are less efficiently digested, e.g. because they are swallowed whole rather than broken up in the jaws, or pass through the digestive tract relatively quickly.

Sandeel proteins were detected more frequently when larger numbers of sandeels, as determined from otolith counts, had been eaten, suggesting that there is a minimum detectable amount of protein.

The lower rate of detection of sandeels from proteins as compared to hard parts does not imply that the serological approach is less useful. Firstly, the antiserum may not detect all species of sandeel; indeed it is possible that antisera could be used to distinguish the species of sandeel eaten, something which is almost impossible from hard parts. Secondly, proteins may be egested over a shorter timescale than otoliths: there is evidence from captive feeding experiments that some otoliths are retained in seal digestive tracts over several days (e.g. Harvey, 1988).

The low rate of detection of sandeel proteins in common seal faeces in February and March 1988, despite the high frequency of occurrence of hard parts, perhaps requires further explanation. Deterioration of proteins during frozen storage is unlikely to be a factor, since detection rates were high in samples from August 1987 which had been 
stored over a longer period. It is possible that the seals were feeding on a different species of sandeel, e.g. A. tobianus during the first quarter of the year. Changes in seal diet and/ or activity patterns may also affect protein detectability due to contingent changes in passage rates (Prime \& Hammond, 1987; Harvey, 1988). The number of gadid otoliths present in the samples was high in February and March and it is possible that many of the sandeel remains in these two months were from sandeels eaten by cod and whiting. If so, the serological approach, combined with examination of hard parts, might provide a means to differentiate direct and secondary ingestion.

Both conventional and novel methods indicate that sandeels were an important component of the diets of common seals and grey seals in the Moray Firth, as previously suggested by examination of digestive tract contents (Pierce et al., 1989, in press a). During 1988 , there was a clear seasonal pattern in the incidence of sandeels in common seal faeces, with sandeels being particularly prevalent in the summer (see Pierce et al., in press b, for further discussion).

In the present study, antisera were successfully applied to detection of sandeel protein residues in seal faeces samples collected in the field, and the approach is of potentially wide applicability in the study of the role of sandeels, and of other prey species, in marine ecosystems.

This work forms part of a joint project between the Department of Agriculture and Fisheries for Scotland, Aberdeen, and the University of Aberdeen, funded by theScottish Office. We are grateful to the Sea Mammal Research Unit for allowing us to carry out feeding trials with grey seals held on their behalf; P. Reijnders for permission to work at Texel and assistance with the seal feeding trials; the Sea Life Centre and Skegness Natureland Marine Zoo for allowing us to collect faeces from their seals; I. Clark, M. Grisley and V. Pratt for assistance with raising and testing antisera; L. Calder, I. Diack, S. Frears, J. Hislop, S. Jackson, W. MacDonald, R. MacKenzie, A. Miller, D. Miller, C. Robertson, A. Ross, N. Rowberry, and P. Thompson for assistance collecting and processing samples; A. Lucas for taking photographs; DAFS Marine Laboratory, Aberdeen, for provision of fish and seal carcasses. We thank R.S. Bailey, and an anonymous referee, for useful comments on the manuscript.

\section{REFERENCES}

Bailey, R.S., 1986. Food consumption by seabirds in the North Sea in relation to natural mortality of exploited fish stocks. International Council for the Exploration of the Sea (CM Papers and Reports), G: 5,8 pp.

Boreham, P.F.L. \& Ohiagu, C.E., 1978. The use of serology in evaluating invertebrate prey/ predator relationships: a review. Bulletin of Entomological Research, 68, 171-194.

Boyle, P.R., Grisley M.S \& Robertson, G., 1986. Crustacea in the diet of Eledone cirrhosa (Mollusca: Cephalopoda) determined by serological methods. Journal of the Marine Biological Association of the United Kingdom, 66, 867-879.

Daan, N. (ed.), 1989. Data Base Report of the Stomach Sampling Project 1981. Copenhagen: International Council for the Exploration of the Sea. [Cooperative Research Report 164.]

Feller, R.J. \& Gallagher, E.D., 1982. Antigenic similarities among estuarine soft-bottom benthic taxa. Oecologia, 52, 305-310.

Feller, R.J., Taghon, G.L., Gallagher, E.D., Kenny, G.E. \& Jumars, P.A., 1979. Immunological methods of food web analysis in a soft bottom benthic community. Marine Biology, 54, 61-74. 
Grisley, M. \& Boyle, P.R., 1985. A new application of serological techniques to gut content analysis. Journal of Experimental Marine Biology and Ecology, 90, $1-9$.

Grisley, M. \& Boyle, P.R., 1988. Recognition of food in Octopus digestive tract. Journal of Experimental Marine Biology and Ecology, 118, 7-32.

Harkonen, T., 1986. Guide to the Otoliths of Bony Fishes of the Northeast Atlantic. Hellerup, Denmark: Danbiu ApS.

Harvey, J.T., 1988. Population Dynamics, Annual Food Consumption, Movements, and Dive Behaviors of Harbor Seals, Phoca vitulina Richardsi, in Oregon. PhD Thesis, Oregon State University.

ICES, 1989. Report of the multispecies assessment working group. International Council for the Exploration of the Sea (CM Papers and Reports), Assessment 20, $125 \mathrm{pp}$.

Kunzlik, P.A., 1989. Small fish around Shetland. In Seabirds and Sandeels. Proceedings of a seminar held in Lerwick, Shetland, 1988 (ed. M. Heubeck), pp. 38-49. Lerwick: Shetland Bird Club.

McConnell, B.J., Prime, J.H., Hiby, A.R. \& Harwood, J., 1984. Grey seal diet. In Interactions Between Grey Seals and UK Fisheries, pp. 148-153. Cambridge: SMRU, NERC.

Payne, P.M., Nicolas, J.R., O'Brien, L. \& Powers, K.D., 1986. The distribution of the humpback whale, Megaptera novaengliae, on Georges Bank and in the Gulf of Maine in relation to densities of the sandeel, Ammodytes americanus. Fishery Bulletin. National Oceanic and Atmospheric Administration of the United States, 84, 271-277.

Pierce, G.J., Boyle, P.R. \& Diack, J.S.W., in press a. Digestive tract contents of seals in Scottish waters: comparison of samples from salmon nets and elsewhere. Journal of Zoology.

Pierce, G.J., Boyle, P.R. \& Thompson, P.M., 1990a. Diet selection by seals. In Trophic Relations in the Marine Environment. Proceedings of the 24th European Marine Biology Symposium (ed. M. Barnes and R.N. Gibson), pp. 222-238. Aberdeen: Aberdeen University Press.

Pierce, G.J., Diack, J.S.W. \& Boyle, P.R., 1989. Digestive tract contents of seals in the Moray Firth area of Scotland. Journal of Fish Biology, 35 (supplement A), 341-343.

Pierce, G.J., Diack, J.S.W. \& Boyle, P.R., 1990b. Application of serological methods to identification of fish prey in diets of seals and dolphins. Journal of Experimental Marine Biology and Ecology, 137, 123-140.

Pierce, G.J., Thompson, P.M., Miller, A., Diack, J.S.W., Miller, D., \& Boyle, P.R., in press b. Seasonal variation in the diet of common seals in the Moray Firth. Journal of Zoology.

Prime, J.H. \& Hammond, P.S., 1987. Quantitative assessment of gray seal diet from fecal analysis. In Approaches to Marine Mammal Energetics (ed. A.C. Huntley et al.), pp. 165-182. Lawrence, Kansas: Society for Marine Mammalogy.

Svendson, P.J., 1973. Fused rocket immunoelectrophoresis. Scandinavian Journal of Immunology, 2 (supplement 1), 69-70.

Walter, C.B., O'Neill, E. \& Kirby, R., 1986. 'ELISA' as an aid to the identification of fish and molluscan prey of birds in marine ecosystems. Journal of Experimental Marine Biology and Ecology, 96, 97-102.

Weeke, B., 1973. Crossed immunoelectrophoresis. Scandinavian Journal of Immunology, 2 (supplement 1), 47-56.

Wheeler, A., 1969. The Fishes of the British Isles and North-West Europe. London: Macmillan. 